UDK 78.037.5Globokar V.

Tjaša Ribizel

Filozofska fakulteta Univerze v Ljubljani

Philosophical Faculty, University of Ljubljana

\title{
Surrealizem v ustvarjalnosti Vinka Globokarja: na primeru skladbe Zlom
}

\section{Surrealism in Creativness of Vinko Globokar: in the case of composition Zlom}

Prejeto: 15. februar 2010

Sprejeto: 1. maj 2010

Ključne besede: Vinko Globokar, avantgarda, surrealizem, kriteriji identifikacije nezavednega, skladba Zlom

\section{IZVLEČEK}

Prispevek želi opozoriti na določene vporednice med ustvarjalnostjo Vinka Globokarja in surrealizmom. Te vzporednice so podrobneje prikazane s pomočjo analize skladbe Zlom. Pri tem so izpostavljene tri ravni ustvarjanja in te so tehnična plat, poetološke iztočnice in raziskovanje psiholoških, socialnih ter humanističnih tem.

\author{
Received: 15th February 2010 \\ Accepted: 1st May 2010
}

Keywords: Vinko Globokar, Avant garde, surrealism, identification criteria of subconsciousness, composition Zlom

\section{ABstract}

The contribution draws attention to certain paralleles between Vinko Globokar creativeness and surrealism. These parallels are represent by the analysis of composition Zlom. Three creative sides are exposed and this are the tehnical side, poetical issues and the research of psychologic, social and humanistic themes.

Muzikološka literatura označuje Vinka Globokarja kot avantgardnega ustvarjalca. Avantgardo razumemo kot vodilno formacijo v zgodovini razvoja modernizma. Gre za napredno gibanje, ki je v umetnost vneslo novosti kot so na primer aleatorika, eksperimentalno in instrumentalno glasbeno gledališče ter druge. V glasbeni avantagrdi je v ospredje postavljena radikalna glasbena inovacija, eksperimentalna glasbena praksa, zunajglasbena praksa, postavantgardna in retroavantgardna glasbena praksa. ${ }^{1}$ Termin se uporablja tudi kot izraz za umetniško delo, žanr, ki se v določenem obdobju smatra kot 
eksperimentalno ali tehnično napredno. ${ }^{2} \mathrm{~S}$ temi avantgardnimi značilnostmi se srečamo tudi v ustvarjalnem opusu Vinka Globokarja.

Za Globokarjevo ustvarjalnost je značilno odkrivanje novih zvočnih sredstev, novih, še neuporabljenih instrumentov, novih načinov vzbujanja zvoka oziroma igranja in uvajanja novih oblik poudarjenega soustvarjanja med ustvarjenim delom in izvedbo le-tega. Na eni strani torej Globokar razširja reproduktivne zmožnosti posameznih instrumentov, na drugi strani sistematično preureja klasična glasbena izrazila in oblike ustvarjanja. Tako sta v ospredju njegove ustvarjalnosti premišljen eksperiment in improvizacija.

V enem od intervjujev je nekoč dejal:

„Če je beseda avantgardist psovka, potem me prav nič ne moti, če mi jo kdo nadene. Težje pa jo prenesem, če je pohvalne narave. "³

Avantgardist naj bi bil tisti, ki si prizadeva za uveljavitev nove smeri, zlasti v umetnosti. Ta opredelitev v bistvu nekako ni povezana z Globokarjem. Leon Stefanija je o njem zapisal:

„Globokar ne stremi za novim zavoljo novega in ne ustvarja za jutri, temveč za danes, ki izpreteklosti beži v prihodnost in ki skozi njegove oči skriva večprihodnosti kakor težko opredeljiva in za avantgardiste tako značilna ideja o njej. Obenem pa nikoli ni zavzel niti negativnega niti elitističnega stališča do tradicije. " ${ }^{4}$

Torej je ta izjava povezana z njegovim pogledom na svet, življenje, družbo, ki se nenehno spreminja, z življenjskim nazorom ter njegovo poetiko. Globokarjeva zgoraj napisana izjava je na eni strani povezana s spremembo, preobratom v glasbeni praksi in tudi družbi. Vendar, če povzamem navedke Nikša Glige, da skladatelji odvračajo uporabo epiteta "avantgardist « zaradi pomanjkljivosti, ki se pojavljajo v povezavi termina avantgardizem in nova glasba, pa termin avantgardizem ni najboljši primer distinkcije med novo glasbo prve in druge polovice 20. stoletja, ker ne sledi dosledno načelom, ki jih s sabo prinaša uporaba pojma nova glasba. ${ }^{5}$ Oznaka nova glasba se nanaša na glasbo 20. stoletja, ki se prične s Schönbergovim rušenjem tonalitete - atonalna glasba, sledi serializem in kot reakcija na serializem se pojem nova glasba pojavi v aleatoriki in tudi v improvizaciji. ${ }^{6}$ Do preobrata, oziroma odklona od termina avantgarda, kot ga opisuje Gligo, je Globokar v svoji ustvarjalnosti prešel sredi osemdesetih let, ko se je začel ukvarjati z vprašanji reagiranja med glasbeniki, improviziranja in psihološkimi interakcijami pri glasbeni reprodukciji. Pred tem so pa njegove prve skladbe težile h glasbeno ne preveč zahtevnemu, torej na prvi pogled dokaj »razumljivemu« glasbenemu stavku.

V določenih pogledih se njegovo delo približuje ali povezuje tudi s temami, ki bi jih lahko uvrstili v surrealizem, oziroma nadrealizem, tj. umetniško smer znotraj avantgarde. ${ }^{7}$ O surrealizmu lahko govorimo kot o zadnjem velikem gibanju v zgodovini avantgarde,

Gligo, Nikša. Pojmovni vodič kroz glazbu 20. stolječa. Zagreb: Matica hrvatska, 1996, 17.

Gaberc, Slavko. „V čarobnem laboratoriju zvoka Vinka Globokarja.« Primorski dnevnik 59 (2003), 19.

Leon, Stefanija. O glasbeno novem. Ljubljana: Študentska založba, 2001, 103.

Gligo, Nikša. Problemi Nove glazbe 20. stoljeća: Teorijske osnove i kriteriji vrednovanja. Zagreb: Muzički informativni centar Koncertne direkcije Zagreb, 1987, 37.

Gligo, Nikša. 1996, 177.

Miško, Šuvaković. Pojmovnik moderne i postmoderne likovne umetnosti i teorije posle 1950. Beograd - Novi Sad: Srpska akademija nauka i umetnosti Prometej, 1999, 259. 
v katerem je prišlo do paradoksalnega širjenja avantgardističnih zamisli emancipacije, osvoboditve ali pa rekonstrukcije tradicionalnih temeljev umetnosti, kot so imitacija, mimezis, fikcija in "naracija $z$ novimi cilji - soočanje z nezavednim in rezultati soočanja po načrtu individualnosti, kolektiva, politike, morale in umetnosti. ${ }^{8}$

V surrealizmu so uporabljene različne tehnike, ki so umetniški smeri dale karakteristično oznako. Značilno je dokumentiranje, opisovanje ali prikazovanje nezavednega. Pomembna je t. i. paradoksalna tvorba v obliki pisanja ali risanja, ki poteka brez sodelovanja človekove zavesti in to predstavlja rezultat človeškega dela, ta pa je posledica nezavednega delovanja. Da bi to skušali razumeti kot produkt nezavednega, je André Breton ${ }^{9}$ ponudil 7 kriterijev identifikacije nezavednega ${ }^{10}$. Med njimi so tri točke, ki jih lahko povežemo z ustvarjalnim opusom Vinka Globokarja. Te tri točke so element skritega ali prikritega, element abstraktnega in konkretnega ter negiranje fizičnih zakonov.

Nekaj osnovnih primerov nam ponudi že odgovor na vprašanje kje so te točke razvidne. To so elementi, s katerimi skladatelj ustvarja in ki mu hkrati ponujajo kompozicijsko rešitev. Na tem mestu v ospredje stopa predvsem šesta točka, torej negiranje fizičnih zakonov. Skladatelj pri obravnavi parametrov namreč včasih namenoma uporablja določene ekstremne višine, trajanja, dinamične stopnje, da bi s tem dosegel poseben učinek, praviloma vezan na psihološko ali idejno hotenje glasbenega dela.

Rečemo lahko tudi, da ta pojav srečamo pri skladbah kot je Discours $I I I^{11}$ kjer se preobremenjenost interpreta pojavi po eni strani na mestih, ki so povezani $z$ artikulacijo in ekstremnimi višinami, pri katerih izvedba skoraj ni več izvedljiva, in na drugi strani kjer so rezultati dobljenih zvočnih barv določeni vnaprej, vendar so fizično nedosegljivi. ${ }^{12}$ Podoben primer zasledimo tudi v Globokarjevi skladbi $Z l o m^{13}$. Na nekaterih mestih, prav tako kot v navedenem primeru skladbe Discours, izstopa dinamika, ki lahko zaradi prehitrega izvajanja odstopa od dejanske vrednosti.

Poleg prej omenjenega moram navesti tudi ravni in cilje, ki določajo Globokarjevo glasbeno delovanje.

Pri opazovanju tehnične plati ustvarjanja vidimo, da se je Globokar ukvarjal z raziskovanjem zvočne barve človeškega glasu in zvočne barve instrumentov ter povezav med barvo glasu in instrumentov. Tu so na primer uporaba glasu kot instrumenta, kar zasledimo v skladbah Traumdeutung ${ }^{14}$ ter Discours $I I^{15}$. Srečamo tudi obraten primer, kjer želi instrument uporabiti kot glas. V ciklusu Discourjev ${ }^{16}$ je želel, da bi instrumenti na nek način govorili, oziroma da bi instrumentalna igra postala vokalna. ${ }^{17} \mathrm{~K}$ temu sodi tudi imitiranje zvoka.

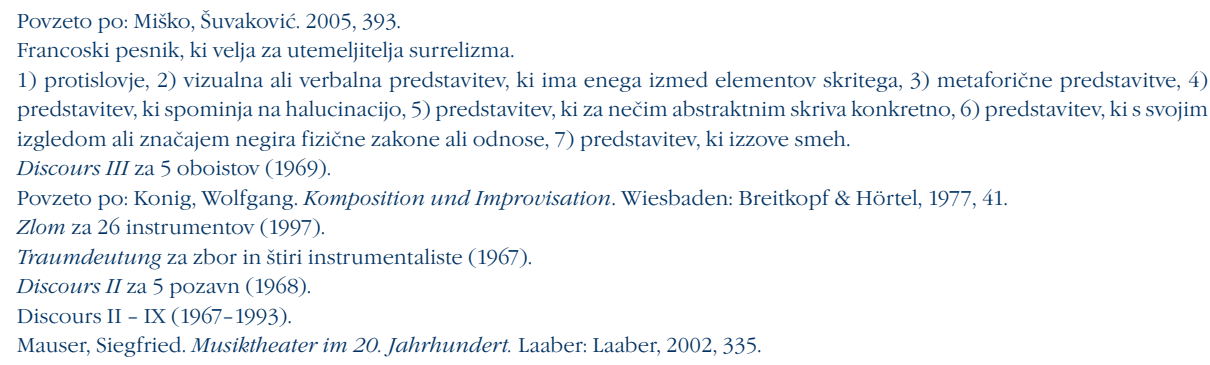


V ospredju raziskovanja so trobilni in pihalni instrumenti, pomembna je tudi uporaba elektronike.

Druga raven so poetološke iztočnice, ker Globokar gradi ali ustvarja z uporabo treh elementov, ki se nanašajo na glasbo: to so intuicija, emocija ter akcija oziroma reakcija. Vsi trije so povezani z improvizacijo, ki je po mojem mnenju temelj spremembe Globokarjevega glasbenega jezika, prakse od leta 1969. Od tega leta naprej v njegovih skladbah zasledimo tudi, da stopijo v ospredje nove zvočne možnosti ter stimulacija močnega interpretativnega angažmaja. ${ }^{18}$ Sam je o tem dejal:

„Ker sem se želel približati že obstoječim zvočnim rezultatom, sem sprva v glavnem komponiral na temelju estetskih premislekov. Ko sem se usmeril v improvizacijo, sem "strukturiranje" nekoliko zrahljal. V zadnjih letih sem vedno delal na vec ravneh, pri čemer se osnouna raven oblikuje iz globoke, skrajno stroge strukture, iz nekakšnega temeljnega rastra, potem pa poskušam vnesti določene napotke in naloge za instrumentalista ... Improvizacija me je prepričala, kako pomembni so psihični angažma instrumentalista in medsebojna psihična razmerja, ki nastajajo v skupini. ${ }^{19}$

Globokar je improvizacijo, s katero se je sam ukvarjal oziroma se ukvarja, imenoval svobodna improvizacija. Zanj je ta produkt intuitivnega, ki ima korenine v nezavednem delu človeškega razuma. ${ }^{20}$ Globokar v improvizaciji ne išče možnosti ali cilja, da bi naredil predstavo, kot to srečamo v t. i. happeningih, kjer gre za povezavo umetnosti in življenja. Elementi teh predstav so določeni vnaprej, kljub temu imajo akterji tudi prostor ali možnost za improvizacijo. Globokar pa želi v skladbah udejanjiti svobodo ${ }^{21}$, s čimer postane improvizacija neodvisna od kompozicije. Globokar improvizacijo ločuje od sodobne umetnostne glasbe, zato ker zavrača ideološke izpostavitve, to ločevanje pa izkazuje tudi, da izhaja pri delu iz akustičnega rezultata.

Tretja raven je povezana z razvojem človeške osebnosti. Središče Globokarjevega ustvarjanja je namreč človek in z njim povezane teme, ki so lahko psihološke, socialne ali družbene ter humanistične. Pomembna je zunanjost, emocija in človekova notranjost. Vse te ravni se v današnji družbi zapostavljajo. Globokar se pri raziskovanju človeške notranjosti usmeri predvsem na človeški razum, zavest, ki je lahko zavedna ali nezavedna, da bi odkril prikriti razvoj določenih čustev ali stanj. V določeni kompoziciji se usmeri tudi v družbo ali skupino ljudi. Prav na tej tretji ravni, če se vrnem k surrealizmu, lahko najdemo element prikritega ali skritega ter konkretnega ali abstraktnega. S tem je povezana tudi idejna umestitev skladbe Zlom. Skladatelj je o skladbi dejal:

"Zlom je lahko $v$ materiji, to pomeni: nekaj se zlomi, lahko pa se zgodi tudi $v$ psihološkem stanju. Tu gre za nasilen zlom nečesa. To lahko sedaj prenesemo na družbo, posameznika ali pa tudi na železje. $\aleph^{22}$

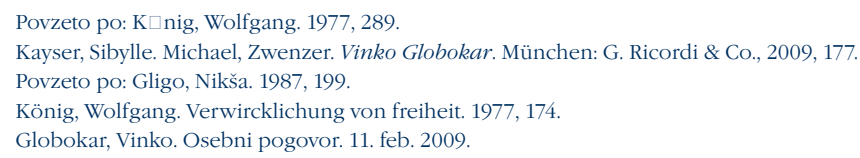


Skladba govori o nasilnem zlomu, kot pravi tudi sam skladatelj, ki je psihološke narave in obravnava zlom politične oblasti. V ospredju je človek, ki se z nasiljem bori proti naravnemu ali naravi, in to privede do zloma, ki je najpogosteje, kot že rečeno, nasilne narave.

Primer prikritega lahko v skladbi zasledimo na mestih, kjer se pojavljata dve slovenski ljudski pesmi. Prva, ki se pojavi v 160. taktu, je pesem² ${ }^{23}$, ki jo lahko uvrstimo med vojaške domoljubne pesmi: izraža močno pripadnost vojakov določeni politični sili, za dosego svojega cilja v boju, ne glede na to, na čigavi strani se posamezniki bojujejo, in pri tem ne kažejo usmiljenja do svojih sovojskujočih. To idejo zloma bi lahko prenesli na dogajanje na Balkanu v obdobju 1990-91, tako v političnem kot tudi v psihološkem smislu posredno in neposredno prizadetih udeležencev. Zlom politične oblasti lahko vidimo v razpadu SFRJ (Socialistične federativne republike Jugoslavije), zlom v psihološkem smislu pa zajema ljudi tistega časa, ki so mislili, da živijo v »bratstvu in enotnosti $\ll^{24}$. Psihološki zlom zajema predvsem ljudi, ki so to opazovali in bili nemočni, da bi kaj storili. Prišlo je torej do vojnega soočenja.

Prej omenjeno pesem lahko razumemo tudi kot resocializacijo vojakov, tistih, ki gredo v boj, se spoznajo z drugačnim načinom življenja, drugimi vrednotami in po vrnitvi v večini primerov doživijo psihološki zlom, ker pride do soočenja različnih vrednot, ki jih pozna ali ima neka določena družba. S tem je prikazano, da vsako nasprotovanje prej ali slej privede do takšnega ali drugačnega zloma.

V delu je zlom prikazan dobesedno, torej element konkretnega, s pokom šipe, tik preden izvajalci začnejo izgovarjati besede: »ne«, »nein«, nočem«, v taktu 280. To pomeni, da doživi človek nasprotje samega sebe, občutek nasprotja je posledica doživetega nasprotja - zloma. Tema kompozicije je torej prikaz vojne ali bolje rečeno prikaz posledic kakršnega koli že nasprotovanja.

S pomočjo dveh omenjenih elementov surrealizma želi skladatelj posredovati idejo skladbe. Ta ideja je primer abstraktnega - s pomočjo prikritega prikazati brezizhodnost iz nastale ali nastalih situacij in s tem brezsmiselnost nastanka pojavov, ki vodijo do stanja brezizhodnosti.

Pri institucionalni ali historiografski zamejitvi Globokarjeve temeljne ustvarjalske naravnanosti je pomembna uporaba zunajglasbenega, folklore ali folklorizmov in improvizacije v posameznih delih. Te tri ravni nas pripeljejo do Globokarjeve temeljne ustvarjalske naravnanosti, in to je glasbeno gledališč ${ }^{25}$. Nekateri interpreti na tem mestu uporabljajo izraz zvočno gledališče ${ }^{26}$. Tudi tu najdemo zametke surrealizma, saj se je ta umetniška smer pojavila najprej v gledališču in literaturi. Ta vidik oblikuje Globokarjevo kompozicijsko dejavnost in s tem tudi stilsko podobo ter umestitev. Dramatična možnost virtuozne predstave, predvsem v Globokarjevi instrumentalni glasbi, je uporabljena za karakterizacijo izrazitega žanra, ki mu termin glasbeno gledališče najbolj ustreza.

23 Za turškim gričem tam je dost fantičev k`se za nas vojskujejo.

24 Ideološki slogan nekdanje SFRJ.

25 Globokar, Vinko: Problem instrumentalnega in glasbenega teatra. Muzikološki zbornik. Ljubljana: Filozofska fakulteta, 1968, 133. Pojem instrumentalni teater se nanaša na instrumentalista, ki s svojim telesom izvaja določene gibe ali zavzema določene položaje, ki so lahko svobodni ali predpisani. Pojem se nanaša na scensko igro, uporabo razsvetljave, mimiko, govor in podobno.

26 Globokar, Vinko. 1968, 135. Pojem se nanaša na scensko igro, uporabo razsvetljave, mimiko, govor in podobno. 
Na tem mestu se moram navezati na eno izmed njegovih izjav:

"Za konkretnost imamo druge umetnosti; beseda v romanu, slika kot objekt, $v$ glasbi pa tega ni, zato moramo izstopiti ven iz glasbe in iskati pomen v drugih umetnostih. $V$ vseh umetnostih moramo pokazati isti profesionalizem kot v glasbi. $^{27}$

V tem primeru se misel vrne h kriterijem identifikacije nezavednega. Kot sem že omenila, je eden izmed kriterijev, ki ga lahko povežemo z Globokarjevim ustvarjanjem, element abstraktnega in konkretnega. Globokar v svojih delih ne išče novih gledaliških žanrov, temveč želi pisati glasbo, ki je ali bo uporabna. Glede na citat je zanj glasba element abstraktnega, ki preide v konkretnost s pomočjo ostalih umetnosti - v Globokarjevem ustvarjanju je to gledališče. Globokarjevo gledališče temelji na simbolično pojmovnem mišljenju in elementi igranega se spajajo s simbolično reprezentacijo. Glasba naj ne bi opisovala vsebine zunajglasbenih idej, temveč bi jim morala držati zrcalo. Tu se lahko spet vrnemo k idejni opredelitvi skladbe Zlom, ki želi prek uporabe folklornih elementov konkretno prikazati že nastali ali nastajajoči problem.

Globokar v svojih skladbah in s tem tudi v Zlomu vedno opozarja na dogajanje okoli sebe in želi s svojimi kompozicijami opozoriti na vzorce, ki jih dela družba ali določen družbeni sistem in so lahko večkrat usodne v negativnem smislu. Zanj je glasba orodje, ki izraža preseganje razumskega spoznanja ali v primeru surrealizma zavednega. To orodje je tisto, ki omogoča nadgradnjo njene osnovne biti in hkrati osmisli skladateljevo idejo v luči razumevanja individuuma in ta individuum oziroma poslušalec je tisti, ki lahko razvija ali razvije idejo razumevanja. Lahko bi rekli, da skuša poslušalec interpretirati glasbene kode, kode nezavednega in jih prenesti na raven zavednega.

\section{SUMMARY}

Musicological literature charaterizes Vinko Globokar as an Avant garde creator. One of artistic directions within Avant garde is surrealism.

Surrealism is typically characterised by documenting, describing or showing the unconscious. Andre Bréton was the one who identified seven criteria of unconscious identification. Among these criteria there are also three elements that can be found in the creativity of Vinko Globokar and which are the disguised or hidden elements, the abstract or concrete, and the element of negating the physical laws.

In tehnical aspects we find the element of denying physscal laws, where results are determined in advance timbres, but they are physically inaccessible or where congestion occurs in urban interpretations associated with articulation and extreme altitudes, where implementation is no longer feasible.
In the poetic level we have improvisation which is the product of intuition and has its roots in the unconscious part of the human mind.

The third level is associated with the development of human personality. At this level we find disguised or hidden and abstract or concrete elements. Those two elements are found within the song $\mathrm{Zlom}$. The song talks about political power and violent collapse. In the foreground there is a man who is struggling with violence against natural or the nature, and the result is a fracture. The example of a disguised element can be traced in the song in places where two Slovenian folk songs appear. An element of the concrete appears with window bangers. This means that a man sustains himself opposite, a sense of conflict is the result of an experienced conflict -a fracture.

Through these two surrealism elements the composer wants to communicate the idea of the song. This idea is an example of an abstract element from a discreete display hopeless or arising out of 
this situation and the meaningless emergence of phenomena that lead to the hopeless situation. In Globokar's creativity, music is an abstract element that turns into?the concrete with the help of other arts - in his creativity this is the theater.

Globokar feels music as a gear which is beyond the rational knowledge or - in the case of surrealism - music is consciousness, a feeling of human social and psychological conditioning. This tool can upgrade its core and at the same time conceive the composer's idea in the light of understanding the individual; an individual or a listener is the one who develops or is developing the idea of understanding. We can say that the listener tries to interpret the music code and transfer the unconscious code to the conscious level. 